\title{
The Effect of Principal Leadership and School Culture on Teachers' Discipline of SDN Banding Agung
}

\author{
Wahyuni Dewi ${ }^{1 *}$, Yasir Arafat ${ }^{2}$, Alhadi Yan Putra ${ }^{2}$ \\ ${ }^{1}$ SD Negeri 02 Banding Agung Kabupaten OKU Selatan, South of Sumatera, Indonesia \\ ${ }^{2}$ Universitas PGRI, Palembang, Indonesia \\ *Corresponding author. Email: wahyunidewi2908@gmail.com
}

\begin{abstract}
The leadership style adopted by the principal affect the school vision. The pedagogical approach implements psychological and familial approaches in implementing work discipline between teachers and principal. This study uses a descriptive quantitative approach. This study analyses the effect of the independent variables, namely the Principal Leadership (X,) and School Culture $\left(\mathrm{X}^{2}\right)$ on the dependent variable, namely Teacher Work Discipline (Y) SD Negeri in Banding Agung District. After analysing the research, the researcher concludes as follows: (1) There is a significant effect of the principal's leadership on the work discipline of public elementary school teachers in Banding Agung District as 50.3\%, (2) There is a significant effect of school culture on the teachers discipline of elementary school in Banding Agung District of $28.6 \%$, (3) There is a significant influence of principal leadership school culture and the work discipline of elementary school in Banding Agung District of 17.7\%.
\end{abstract}

Keywords: Quantitative Approach, Leadership, Work Culture, Work Discipline

\section{INTRODUCTION}

The discussion of a science's symptoms is called education management [1]. In an education unit, the principal is the school manager.

The principal as an educational leader has a tight responsibility; adequate preparation, both mentally and psychologically, in carrying out his duties, especially in dealing with all the problems and challenges faced to create and provide comfort for teachers and students. An elementary school principal's ability to lead is very influential in increasing teacher work and improving and creating an effective and efficient learning process. The leadership applied by the principal will affect the process of creating comfort, order in the learning process, especially on teacher work discipline and teacher performance.

The leadership style adopted by the principal affects the realization of the school vision. There are various kinds of leadership styles applied by school principals; authoritarian leadership tends to be responded to negatively by their subordinates by showing lowperformance levels and work productivity. On the contrary, leadership styles can be applied in a directive, supportive and participatory way.

A school principal must provide a charismatic leadership effect, become a role model, engage and involve stakeholders to achieve the school vision. In line with Wahab [2], "Leadership means someone's capability and readiness to influence, encourage, invite, guide, engage, involve people or groups to accept the effect and do something in achieving specific goals".

Based on a preliminary survey of teachers' impressions of teacher success conducted by researchers, including several indicators, the research instrument for teacher performance consists of four main competencies including pedagogical competence, personal competence, professional competence, and social competence in Public Elementary Schools in Banding Agung District, Ogan Komering Ulu Selatan Regency. It was reported that there is a lack of harmony between work culture and the work discipline of teachers in SDN in Banding Agung District. It affects teachers' discipline. Meanwhile, the principal tends to apply psychological and kinship approaches to implement work discipline between the leader and his subordinates. It causes compliance, among others.

Meanwhile, in terms of personal competence, most teachers confirmed that the principal does not take criticism, the teachers do not have similar opportunities to play the role as one of the decision-makers. In terms of professional competence, the principal explained that teachers are not capable of using learning media. Meanwhile, on social competence, fellow teachers, there 
are still teachers who are not obedient to the rules that apply to schools.

Based on observations, decreasing teacher performance and productivity in SD Negeri in Banding Agung Subdistrict due to the school principal and school culture's leadership style and some teachers' work discipline tend to be ignored resulting in disharmony the organization affects organizational performance. However, teacher performance and productivity in teaching are the primary keys to the academic units' learning process.

One of the performance indicators is the increase of work discipline. The teacher discipline reflects the teachers' attitude and personality in obeying all the rules in school. Employee work discipline in an organization is one of the functions of human resource management because, with conditions full of discipline, employees can be expected to become substantial milestones in an organization to achieve goals. Discipline is a condition in an organization where employees follow the rules and behave according to acceptable organization standards [3]. The notion of work discipline is an attitude and behaviour that shows employee obedience to organizational rules. That is, attitudes and behaviour to obey organizational rules emerge from within. Intention can also be interpreted as a desire to do something or a willingness to conform to the rules. Attitudes and behaviour in work discipline are characterized by various initiatives, willingness, and will to obey the rules. The teachers' attitude in obeying the rules to enforce discipline is born and created when there is an atmosphere created by the school principal; for example, in school attendance, the principal is present one hour before lessons start every day. It will positively impact teachers to follow school principal attendance because they do not want to be late and shame him.

Attitudes and behaviour are a reflection of work culture. According to Nawawi [4], work culture is a habit that is carried out repeatedly by employees in an organization, violations of this habit do not have strict sanctions, but morally organizational actors have agreed that these habits are habits that must obey in the framework of carrying out work to achieve goals. Meanwhile, according to Hartanto [5], work culture is a manifestation of life in the workplace. Work culture is a system of meanings related to work, work, work interactions, which are mutually agreed upon, and used in daily work life.

\section{METHODS}

This study employed descriptive correlational research methods with a quantitative approach. Sukmadinata [6] explains that correlational research is employed to determine the relationship between variables and other variables, expressed by the coefficient of relations and statistical significance. Arikunto [7] explains that "correlational research is research conducted by researchers to determine the level of the relationship between two or more variables, without making changes, additions or manipulations to existing data". In this study, there are independent variables $\left(\mathrm{X}_{1}\right)$, Principal Leadership and Teacher Work Culture $\left(\mathrm{X}_{2}\right)$, and the dependent variable (Y), namely Teacher Work Discipline. The study was conducted on 49 teachers as respondents. In this study, the analysis focused on the effect of the independent variables, namely the Principal Leadership $\left(\mathrm{X}_{1}\right)$, and Teacher Work Culture $\left(\mathrm{X}_{2}\right)$ on the dependent variable, Teacher Work Discipline (Y) SDN in Bandung Agung subdistrict.

\section{RESULTS AND DISCUSSION}

Principals and teachers are two factors that influence the standard of education in schools. The Principal's leadership relationship in school organizations entails engaging teachers to have a strong or bad work ethic. Principals and teachers influence leaders and subordinates, play the role to achieve certain goals, especially the quality of education in schools, a synergic and conducive cooperation between the Principal and teachers is needed.

Based on the explanation above, it can be assumed that both the Principal's leadership style and the teachers' work culture have a significant effect on teacher work discipline. Therefore, to improve work discipline or teachers' productivity, schools must provide a comfortable working atmosphere, create a positive and conducive environment both from the leadership system, organizational management and enforcement of regulations. This will create and make teachers perform according to national education standards.

Meanwhile, work productivity or teacher performance will be useful if supported by a comfortable, conducive, and competitive school climate. This situation encourages teachers to be more passionate, disciplined and give good performance in teaching. If the atmosphere of the school climate is not supportive, such as the leadership style of the principal being indifferent to teachers who are diligent and lazy, teachers are often absent or arrive late, reduce teaching hours to students, this will have an impact on the job, or teacher performance decreases. It is as expressed by Robbins "... employees are not loyal, employees neglect such as absenteeism or arriving late, reduce the quality and quantity of work and the rate of work errors increases, ultimately impacting on decreased performance" [8]. To avoid the situation, it is necessary to have a principal leadership style that can create good teacher attitudes and culture, positive teacher discipline levels, and improve teacher performance. This creation will be realized if the principal's leadership style is applied appropriately and is suitable for the school atmosphere. It is expected to create a comfortable working atmosphere in the school so that the teacher's 
attitude will be more disciplined and the teacher's performance will look excellent and positive for school learning process activities.

Teacher discipline is a teacher's obedience (compliance) to the rules relating to implementing their duties as educators in school's teaching and learning process. In this regard, the basic theory developed as dimensions and indicators of teacher discipline in the teaching and learning process includes three aspects, namely attendance, implementation of tasks (activities), and follow-up programs, with the reason to know the extent to which the level of teacher discipline in carrying out their duties as educators at school.

Good work discipline reflects the amount of responsibility that must be assumed by a person for the tasks assigned to him and encourages morale in realizing organizational goals. For this reason, discipline in the form of implementing regulations is essential for employees, teachers, and students as a tangible manifestation of supervision in creating school organizational rules. Good work discipline also reflects a teacher's personality who has a high sense of responsibility and has high intellectual and broad insight and various competencies.

Teacher discipline can begin with common behaviours, such as teachers being able to use enough time, having a sense of responsibility for the tasks assigned by the leader, having a sense of belonging and responsibility for class organization, and compiling lesson schedules. It is hoped that with a sense of selfawareness to carry out job discipline and learning discipline, all activities carried out on a daily basis in schools can yield good results in accordance with educational objectives, which are also national education goals. Work discipline has an impact on teacher success in enforcing teachers because discipline is very necessary because work discipline can be a driving force for the ability and motivation to work within set expectations or limits, so it is clear that work discipline should be owned by a teacher to sustain it. the learning process's performance [9].

Teacher discipline can be started from habits that are often carried out, including teachers being able to use sufficient time, having a sense of responsibility for the leader's task, having a sense of belonging and responsibility for the class organization, and compiling lesson schedules. With a sense of self-awareness to carry out work discipline and learning discipline, it is hoped that all activities carried out daily in schools can produce good results by the objectives of education, which are also the goals of national education.

The hypothesis is a temporary answer to the research problem's formulation [10]. There are three research hypotheses: the descriptive hypothesis, the comparative hypothesis, and the associative hypothesis. This study using the associative hypothesis. The associative hypothesis is a temporary answer to the formulation of an associative problem that asks for the relationship between two or more variables [10]. Based on the formulation of the problem the researcher has put forward, the hypothesis in this study is:

$\mathrm{Ha}_{1}$ : There is a positive and significant effect between the principal's leadership on SDN teachers' work culture in Banding Agung District.

$\mathrm{Ha}_{2}$ : There is a positive and significant effect on teacher work culture on SDN teachers' work discipline in Banding Agung District.

$\mathrm{Ha}_{3}$ : there is a positive and significant effect of principal leadership on public elementary school teachers' work culture on discipline in Banding Agung District.

This research was conducted at SD Negeri 01, SD Negeri 02, and SD Negeri 06, Banding Agung Subdistrict, Ogan Komering Ulu Selatan Regency; the research period was carried out from November 2020 to December 2020. The study involved 49 respondents (teachers), with 16 respondents from SDN 01, 24 respondents from SDN 02, and 9 respondents from SDN 06 Banding Agung. The research data were collected based on an interview questionnaire on the results of the respondents' answers. Each questionnaire contains closed questions about principal school leadership with 25 questions, 25 questions about teacher work culture, and questions about teacher work discipline, which also consists of 25 questions. Then, the number of questions with closed answers is 75 questions.

The data description presented in this thesis consists of three variables, namely the principal leadership variable $\left(X_{1}\right)$ and the teacher work culture $\left(X_{2}\right)$ as independent variables, while the dependent or dependent variable is teacher work discipline (Y). Each variable is measured by giving questions to 49 respondents, some question items as indicators of these variables. A detailed description of each of these variables in a row and the lowest score, highest score, average value, standard deviation, median, and mode can be seen in the table below: 
Table 1. Descriptive Data on Statistic Research Variable

\begin{tabular}{|c|c|c|c|}
\hline & Leadership & Work Culture & Discipline \\
& & & \\
\hline $\mathrm{N}$ Valid & 49 & 49 & 49 \\
Missing & 0 & 0 & 0 \\
Mean & 77.4000 & 58.2333 & 67.0333 \\
Std. Error of Mean & 1.28080 & 1.18291 & 1.33174 \\
Median & 78.5000 & 58.0000 & 67.0000 \\
Mode & $81.00^{\mathrm{a}}$ & $58.00^{\mathrm{a}}$ & $67.00^{\mathrm{a}}$ \\
Sit. Deviation & 7.01525 & 6.47906 & 7.29423 \\
Variance & 49.214 & 41.978 & 53.206 \\
Range & 29.00 & 32.00 & 28.00 \\
Minimum & 60.00 & 40.00 & 54.00 \\
Maximum & 89.00 & 72.00 & 82.00 \\
Sum & 2322.00 & 1747.00 & 2011.00 \\
\hline \multicolumn{2}{|c}{}
\end{tabular}

Based on the data obtained in the field then processed with a computer assistance program, SPSS. To find out the data description of the teacher work discipline variable (Y), according to the data in table 3.1 above, all data are complete, none of which are defective, marked with no missing data. The variable of teacher work discipline with 49 respondents had an average value of 77.40 , a median of 78.50 , mode 81 , a standard deviation of 7.015 , a minimum value of 60 , a maximum value of 89 , and a total of 2322 . The data shows that the mean and the mode with the median is not much different. It depicts the frequency distribution of the variable teacher job discipline, while the data distribution is normally distributed.

Based on the data obtained in the field then processed with the help of the SPSS program computer. According to the data in table 3.1 above, all data are complete, none of which are defective, marked with no missing data. The leadership variable with 49 respondents had a mean value of 58.23, a median of 58.00 , mode 56, standard deviation of 6,479 , a minimum value of 40 , a maximum value of 72 and a total of 1747. not much different. It illustrates the frequency distribution of the leadership variable.

After researching principal leadership $\left(\mathrm{X}_{1}\right)$, teacher work culture $\left(\mathrm{X}_{2}\right)$, and teacher work discipline $(\mathrm{Y})$, the researcher will test the hypothesis, namely:

1) There is a significant effect of the principal's leadership on SDN teachers' work discipline in Banding Agung District.

2) There is a significant effect of teacher work culture on public elementary teachers' work discipline in Banding Agung District.

3) There is a significant influence of the principal's leadership and teacher work culture on Public SD teachers' work discipline in Banding Agung District.

\section{CONCLUSION}

After analysing the research, and getting the results of the research, the researcher has the following conclusions: 1) there is a significant effect of the principal's leadership on the SD teachers' work culture in Banding Agung District of $50.3 \%$; 2) there is a significant effect on the influence of teacher work culture on SDN teachers' work discipline in Banding Agung District of $28.6 \%$, and 3) there is a significant influence of the principal's leadership and teachers on work discipline of SD Negeri teachers in Banding Agung District, $17.7 \%$.

\section{ACKNOWLEDGMENTS}

Our deepest gratitude goes to Teachers in SD Negeri 02 Banding Agung OKU Selatan Regency, Chancellor of Palembang PGRI University, Director of the Postgraduate Program of PGRI Palembang University and the Education Management Study Program of PGRI Palembang University, who have supported us in doing this extraordinary thing. This project is funded independently. We also want to thank our Education Management friends who helped us a lot in a short time frame to complete this project.

\section{REFERENCES}

[1] Suriasumantri, J. S. (2005). Filsafat Ilmu: Sebuah Pengantar Populer [Philosophy of Science: A Popular Introduction]. Jakarta: Pustaka Sinar Harapan.

[2] Wahab, A., \& Solichin. (2011). Analisis Kebijasanaan: dari Formulasi ke Implementasi Kebijaksanaan Negara [Policy Analysis: from Formulation to Implementation of State Policy]. Jakarta: Sinar Grafika. 
[3] De Cenzo, et.al. (2010). Fundamentals of Human Resource Management. 10th ed. USA: John Wiley \& Son.

[4] Nawawi, U. I. (2003). Budaya Organisasi Kepemimpinan dan Kinerja [Organizational Culture Leadership and Performance]. Depok: Kencana.

[5] Hartato, S. (2010). Buku Ajar Pelayanan KB [Family Planning Services Textbook]. Yogyakarta: Pustaka Rihama.

[6] Sukmadinata, N. S. (2013). Metode Penelitian Pendidikan [Educational Research Methods]. Bandung: Remaja Rosdakarya.

[7] Arikunto, S. (2013). Prosedur Penelitian Suatu Pendekatan Praktik [Research Procedure A Practical Approach]. Jakarta: Rineka Cipta.

[8] Robbins, S. P. (2011). Organizational Behaviour. San Diego State University: Prentice Hall.

[9] Alhusaini, A., Kristiawan, M., \& Eddy, S. (2020). Pengaruh Motivasi Kerja dan Disiplin Kerja terhadap Kinerja Guru [The Effect of Work Motivation and Work Discipline on Teacher Performance]. Jurnal Pendidikan Tambusai, 4(3), 2166-2172. Retrieved from https://jptam.org/index.php/jptam/article/view/693

[10] Sugiyono. (2015). Metode Penelitian Kuantitatif, Kualitatif dan $R$ \& $D$ [Quantitative Research Methods, Qualitative and $R \& D$ ]. Bandung: Alfabeta. 